\title{
A Five Year Longitudinal Study of the Educational Environment in a Newly Integrated Medical Curriculum
}

\author{
Syed I. Shehnaz ${ }^{1,2}$
}

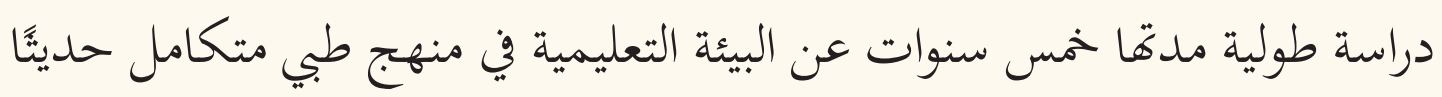

سيد إلياس شهناز

\begin{abstract}
Objectives: The College of Medicine at Gulf Medical University (GMU), Ajman, United Arab Emirates, was subjected to a curricular reform, which shifted the institution from a traditional curriculum to a hybrid, studentcentred, integrated curriculum. There are no previous studies analysing the consequences of such a curricular modification on the educational environment (EE). Therefore, this study aimed to analyse the EE of a pioneer cohort of the innovative curriculum over their five-year course of study. Methods: This prospective longitudinal study was conducted between September 2009 and September 2013 at the College of Medicine. The Dundee Ready Education Environment Measure questionnaire was completed by a pioneer cohort of students at the start of each academic session for five consecutive years. The mean overall, subscale and individual statement scores were evaluated using the Kruskal-Wallis and Wilcoxon-rank sum tests. Results: A total of 178 responses were collected (response rate: 90.4\%). The mean overall score throughout the five years of study was 130/200. A significant difference in the scores $(P<0.05)$ was observed as the students proceeded through the course. The overall and subscale scores were significantly higher in the first and final years of study. Analysis of the statements recognised the medical knowledge of the teachers' and students' awareness of empathy and social interactions as persistent strengths of the college over the entire course of study. A curricular overload, a want for support systems for stressed students, students' waning interest levels and assessment strategies emerged as areas that warranted further attention. Conclusion: The pioneer cohort of the new curriculum rated their EE as positive throughout their five years of study at GMU. An examination of individual statements revealed the programme's strengths and areas for improvement for the institution.
\end{abstract}

Keywords: Curriculum; Environment; Longitudinal Study; Medical Students; Perception; Undergraduate Medical Education; United Arab Emirates.

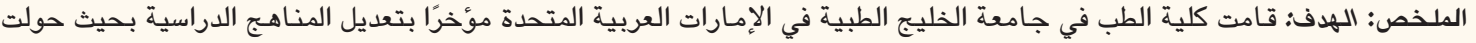

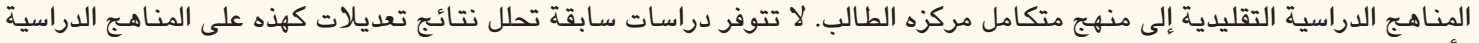

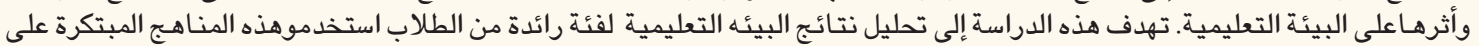

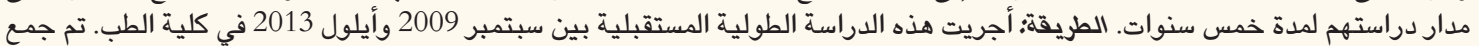

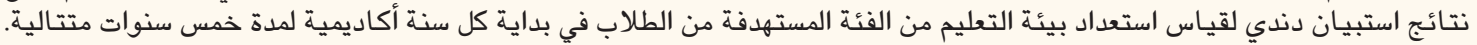

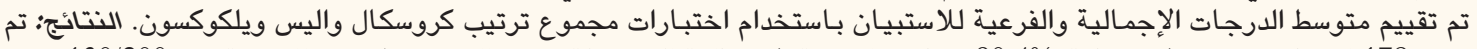

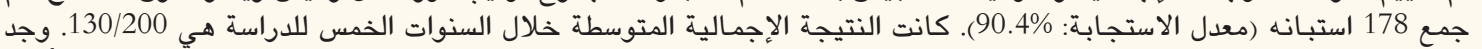

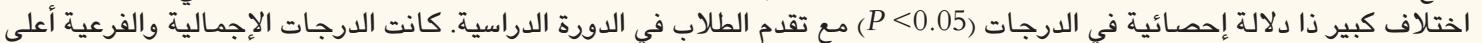

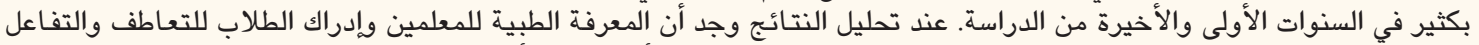

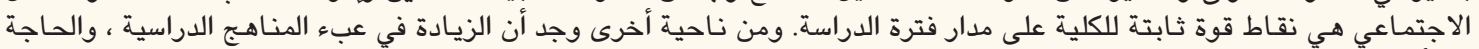

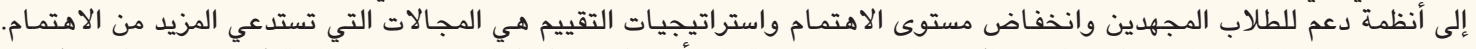

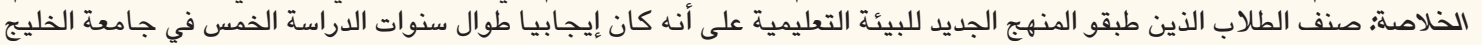

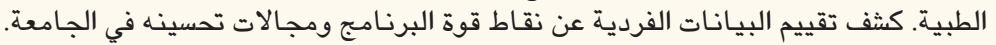
الكلمات المفتاحية: المناهج الدراسية؛ بيئة؛ دراسة طولية؛ طلاب الطب؛ المعرفة؛ التعليم الطبي الجامعي؛ الإمارات العربية المتحدة.

\footnotetext{
Advances in KNOWLEDge

The pioneer cohort of students perceived a sustained positive EE in the new organ-system-based integrated curriculum over their entire course of study.

A curricular overload, a want for a support system for stressed students, students' waning interest levels and assessment strategies emerged as persistent areas that warrant further development.
}

\section{Application to Patient Care}

Students are major stakeholders in a medical curriculum and their experiences in the EE can influence their learning outcomes. 
As the EE is deeply influenced by the curriculum, students' perceptions of their EE can provide indispensable input for designing better curricular strategies to maximise learning.

Enhanced learning outcomes and improved curricular designs will eventually have bearing on the achievements, satisfaction and success of future doctors.

Learning and teaching approaches can be developed that foster problem-solving skills in future physicians for the benefit of the communities they will serve.

$\mathrm{T}$ HE EDUCATIONAL ENVIRONMENT (EE) OF ANY institution influences the scholastic experiences of the students. ${ }^{1,2}$ Favourable educational outcomes are strongly shaped by an encouraging EE. As "any new curriculum cannot be sensibly separated from its learning milieu, with the introduction of a new curriculum creating repercussions in the learning milieu, and these repercussions, in turn, affecting the new curriculum and moderating its impact," the active curriculum of any institution has a primary influence on its EE. ${ }^{1}$

Students' perceptions of EEs have been measured through the Dundee Ready Education Environment Measure (DREEM) questionnaire. ${ }^{2-5}$ DREEM has been used to give institutional feedback, assess new or changed curricula, compare different medical schools' EEs and evaluate multiple teaching sites' EE differences. ${ }^{6-12}$ Students' expectations of EEs at the start of the first year have also been compared with their actual experiences. ${ }^{13}$ Although studies have compared the perceptions of students at two given points in time, no studies have scrutinised the long-term consequences of curricular reform on EE. ${ }^{13-16}$

The Bachelor of Medicine Bachelor of Surgery (MBBS) programme at the College of Medicine (CoM) at Gulf Medical University (GMU), Ajman, United Arab Emirates, is a five-year programme followed by a one-year internship. The CoM reformed its curriculum from a discipline-based model to a student-centred, modular, integrated curriculum. In the English-medium programme, the new curriculum is divided into three phases. Phase one consists of one year and introduces the basics of medical science. Phase two is two years and includes studying the organ systems in an integrated manner. Phase three is two years and consists of clinical clerkship training. During the course of this study, the final year of the clinical clerkship training took place in a tertiary hospital which was not part of the principal teaching hospital.

As curriculum is a partial determinant of an institution's EE, any curricular reform will potentially transform an institution's EE. ${ }^{1}$ However, the long-term effects of GMU's curricular change on EE has not been previously assessed. The EE at GMU, therefore, both prior and subsequent to the curricular change, was analysed. ${ }^{12}$ This study aimed to analyse the EE of the pioneer/first cohort involved in the revised curriculum over their entire course of study and investigate any gender or ethnic differences as they relate to students' perceptions. The longitudinal evaluation of the $\mathrm{EE}$ assessed the impact of the new curriculum as it matured and determined whether changes were occurring in the correct direction. Moreover, the utilisation of a standardised tool, the DREEM questionnaire, for the same cohort over their entire curriculum captured more comprehensive and evolving viewpoints, alleviating any personality differences arising due to the diversity in different cohorts. Subsequently, the results of this study may provide indispensable input for improving the curriculum to maximise student learning.

\section{Methods}

This prospective longitudinal study was conducted between September 2009 and September 2013. The DREEM questionnaire was used to determine the CoM's EE. This questionnaire has 50 statements which are distributed among five subscales-students' perceptions of learning, students' perceptions of teachers, students' academic self-perceptions, students' perceptions of atmosphere and students' social self-perceptions. The statements are scored on a five-point Likert scale ranging from zero for 'strongly disagree' to four for 'strongly agree' with the maximum attainable score of 200. ${ }^{17}$ The DREEM questionnaire underwent pilot testing and explanations were provided for some statements for better understanding.

From the second year onwards, the DREEM questionnaire was administered at the commencement of each academic year for five consecutive years. The questionnaires were distributed to a convenience sample of students attending class on the days that surveys were conducted every year. Any new entrants to the course (i.e. transfer students from other universities or those from a previous batch) were excluded from the study. The research objectives were explained and participants were instructed to answer the questionnaire based on their experiences in the previous academic year. Regular contact with the programme's first cohort emphasising their contribution in resolving issues with the new curriculum and apprising them of publications involving them were strategic in preventing survey fatigue. ${ }^{12}$ 
Table 1: Mean characteristics and mean global Dundee Ready Education Environment Measure scores of the pioneer cohort after a curricular change by year of study $(\mathrm{N}=178)$

\begin{tabular}{|c|c|c|c|c|c|c|}
\hline \multirow[t]{2}{*}{ Characteristic } & \multicolumn{6}{|c|}{ n (\%) } \\
\hline & $\begin{array}{l}\text { First year } \\
(\mathrm{n}=44)\end{array}$ & $\begin{array}{l}\text { Second year* } \\
\quad(n=40)\end{array}$ & $\begin{array}{l}\text { Third year* } \\
(\mathbf{n}=37)\end{array}$ & $\begin{array}{l}\text { Fourth year } \\
\quad(\mathbf{n}=35)\end{array}$ & $\begin{array}{l}\text { Fifth year } \\
(\mathrm{n}=22)\end{array}$ & $\begin{array}{l}\text { All responses } \\
\quad(\mathbf{n}=178)\end{array}$ \\
\hline \multicolumn{7}{|l|}{ Gender } \\
\hline Male & 17 (38.6) & $16(41)$ & $12(33.3)$ & $12(34.3)$ & $9(40.9)$ & $66(37.5)$ \\
\hline Female & 27 (61.4) & $23(59)$ & $24(66.7)$ & $23(65.7)$ & $13(59.1)$ & $110(62.5)$ \\
\hline $\begin{array}{l}\text { Mean age } \pm S D \text { in } \\
\text { years }\end{array}$ & $19.98 \pm 2.0$ & $21.22 \pm 2.1$ & $22.20 \pm 2.5$ & $22.85 \pm 2.28$ & $23.18 \pm 1.05$ & $21.70 \pm 2.37$ \\
\hline $\begin{array}{l}\text { Mean global DREEM } \\
\text { score } \pm \mathrm{SD} \text { (\% of } \\
\text { maximum score) }\end{array}$ & $\begin{array}{c}135.41 \pm 22.13 \\
(67.7)\end{array}$ & $\begin{array}{c}123.33 \pm 22.58 \\
(61.7)\end{array}$ & $\begin{array}{c}130.3 \pm 21.61 \\
(65.2)\end{array}$ & $\begin{array}{c}126.11 \pm 20.96 \\
(63.1)\end{array}$ & $\begin{array}{c}135.27 \pm 14.49 \\
(67.6)\end{array}$ & $\begin{array}{c}129.79 \pm 21.43 \\
(64.9)\end{array}$ \\
\hline$P$ value & - & - & - & - & - & 0.02 \\
\hline
\end{tabular}

DREEM = Dundee Ready Education Environment Measure; SD = standard deviation. "One student did not indicate gender.

Statistical analysis was conducted using Statistical Package for the Social Sciences (SPSS), Version 24 (IBM Corp., Armonk, New York, USA). Means \pm standard deviation in the overall, subscale and individual statement scores between all five years were evaluated with the Kruskal-Wallis test. If any significant variances were observed, pairwise comparisons were used. The Wilcoxon-rank sum and Kruskal-Wallis tests were utilised to analyse gender and ethnic differences, respectively. A $P$ value of 0.05 was considered statistically significant. For analysis, statements were considered as either reflective of excellence, areas that could be enhanced or areas of shortcoming if their mean scores were $\geq 3,2-3$ or $\leq 2$, respectively. The scores for negative statements were reversed so as to facilitate exact conclusions about the statements. High reversed scores indicated that more students disagreed with the statements.

Informed consent was obtained from all participants and their confidentiality was assured. Ethical approval was attained from the Institutional Ethics Review Committee of GMU.

\section{Results}

A total of 178 responses were obtained during the fiveyear course of study (overall response rate: 90.4\%). The response rates for the first to fifth year were $94 \%, 90 \%$, 92.5\%, 97\% and 73\%, respectively. Most respondents were female (62.5\%) and of multi-ethnic descent [Tables 1 and 2]. The majority of students were of Asian descent, from the Indian subcontinent (67.5\%) followed by Africans (20.8\%) and Arabs (11.7\%).

The Cronbach's alpha coefficient was 0.93 which suggests excellent internal consistency and reliability of the DREEM questionnaire with the current sample. Although the Alpha coefficient for the subscale "social self-perceptions" was low, the other subscales indicated satisfactory reliability, with perceptions of learning at 0.82 , perceptions of teachers at 0.75 , academic selfperceptions at 0.75 , perceptions of atmosphere at 0.81 and social self-perceptions at 0.63 .

A significant pattern of difference in the overall scores was observed as the students proceeded through the entire course $(P=0.02)$. The mean overall scores were significantly higher between the first and second year and the fourth and final year of the study when compared to the scores in the second and third years and third and fourth years of study $(P=0.02$ and 0.02 versus 0.09 and 0.06 , respectively). No significant differences were detected between the mean overall scores between the second and third years and between the third and fourth years [Table 1].

Significant differences were identified in the mean subscale scores of students' "perceptions of teachers", "academic self-perceptions" and "perceptions of atmosphere" for all responses. The mean subscale scores of "perceptions of learning", "perceptions of teachers" and "academic self-perception" were statistically significantly higher in the first year of study when compared to the scores in the second year $(P=0.03,0.006$ and 0.007 , respectively). Similarly, higher mean scores were also observed for "perceptions of atmosphere" in the final year as compared to the scores in the fourth year $(P=0.007)$ [Table 2].

Among the five subscales, "academic self-perception" had the highest mean score for all responses and in all the years except in the final year. "Perceptions of atmosphere" was the highest scoring subscale in the final year. In all years, except the third year, and for all responses, the "social self-perceptions" subscale obtained the lowest mean scores. "Perceptions of teachers" was recognised as the subscale with the lowest scores in the third year [Table 2]. 
Table 2: Mean Dundee Ready Education Environment Measure subscale scores of the pioneer cohort after a curricular change by year of study, gender and ethnicity $(\mathrm{N}=178)$

\begin{tabular}{|c|c|c|c|c|c|c|c|c|c|c|c|c|c|c|}
\hline \multirow{3}{*}{$\begin{array}{l}\text { DREEM } \\
\text { subscale } \\
\text { (maximum } \\
\text { score) }\end{array}$} & \multicolumn{14}{|c|}{ Mean DREEM score \pm SD (\% of maximum score) } \\
\hline & \multicolumn{5}{|c|}{ Year of study } & \multirow{2}{*}{$\begin{array}{c}\text { All } \\
\text { responses } \\
(\mathrm{n}=178)\end{array}$} & \multirow{2}{*}{$\begin{array}{c}P \\
\text { value }\end{array}$} & \multicolumn{2}{|c|}{ Gender* } & \multirow{2}{*}{$\begin{array}{c}P \\
\text { value }\end{array}$} & \multicolumn{3}{|c|}{ Ethnicity $^{+}$} & \multirow{2}{*}{$\begin{array}{c}P \\
\text { value }\end{array}$} \\
\hline & $\begin{array}{c}\text { One } \\
(n=44)\end{array}$ & $\begin{array}{c}\text { Two } \\
(n=40)\end{array}$ & $\begin{array}{c}\text { Three } \\
(\mathbf{n}=37)\end{array}$ & $\begin{array}{c}\text { Four } \\
(\mathbf{n}=35)\end{array}$ & $\begin{array}{c}\text { Five } \\
(n=22\end{array}$ & & & $\begin{array}{c}\text { Male } \\
(n=66)\end{array}$ & $\begin{array}{c}\text { Female } \\
(n=110)\end{array}$ & & $\begin{array}{c}\text { Asian } \\
(\mathbf{n}=81)\end{array}$ & $\begin{array}{l}\text { African } \\
(\mathrm{n}=25)\end{array}$ & $\begin{array}{c}\text { Arab } \\
(\mathrm{n}=14)\end{array}$ & \\
\hline $\begin{array}{l}\text { Students' } \\
\text { perceptions } \\
\text { of learning } \\
(48)\end{array}$ & $\overbrace{P=}^{33.36 \pm 5.21}$ & $\begin{array}{c}30 \pm 7.1 \\
(62.5) \\
0.03\end{array}$ & $\begin{array}{c}31.14 \pm 6.2 \\
(64.9)\end{array}$ & $\begin{array}{c}29.94 \pm 6.29 \\
(62.4)\end{array}$ & $\begin{array}{c}32.41 \pm 3.3 \\
(67.5)\end{array}$ & $\begin{array}{c}31.35 \pm 6.03 \\
\quad(65.3)\end{array}$ & 0.60 & $\begin{array}{c}31.8 \pm 7.07 \\
(66.3)\end{array}$ & $\begin{array}{c}31.07 \pm 5.39 \\
(64.7)\end{array}$ & 0.75 & $\begin{array}{c}31.43 \pm 5.89 \\
(65.5)\end{array}$ & $\begin{array}{c}35.12 \pm 6.23 \\
\quad(73.2)\end{array}$ & $\begin{array}{c}28.43 \pm 4.6 \\
(59.2)\end{array}$ & 0.007 \\
\hline $\begin{array}{l}\text { Students' } \\
\text { perceptions } \\
\text { of teachers } \\
(44)\end{array}$ & $\overbrace{P}^{29.98 \pm 5.08}=$ & $\begin{array}{c}27.33 \pm 5 \\
(62.1) \\
.006\end{array}$ & $\begin{array}{c}27.51 \pm 5.13 \\
\quad(62.5)\end{array}$ & $\begin{array}{c}27.89 \pm 5.36 \\
(63.4)\end{array}$ & $\begin{array}{c}29.73 \pm 4.87 \\
\quad(67.6)\end{array}$ & $\begin{array}{c}28.43 \pm 5.18 \\
\quad(64.6)\end{array}$ & 0.02 & $\begin{array}{c}29.52 \pm 5.09 \\
(67.1)\end{array}$ & $\begin{array}{c}27.82 \pm 5.18 \\
\quad(63.2)\end{array}$ & 0.08 & $\begin{array}{c}29.16 \pm 4.3 \\
(66.3)\end{array}$ & $\begin{array}{c}31.48 \pm 5.03 \\
(71.5)\end{array}$ & $\begin{array}{c}25 \pm 5.95 \\
(56.8)\end{array}$ & 0.002 \\
\hline $\begin{array}{l}\text { Students' } \\
\text { academic } \\
\text { self- } \\
\text { perceptions } \\
(32)\end{array}$ & $\begin{array}{c}22.41 \pm 4.13 \\
(70) \\
P\end{array}=$ & $.007 \overbrace{P}^{20 \pm 4.22}=$ & $\begin{array}{c}22.14 \pm 4.1 \\
(69.2) \\
0.005\end{array}$ & $\begin{array}{c}21.31 \pm 3.79 \\
\quad(66.6)\end{array}$ & $\begin{array}{c}21.59 \pm 3.35 \\
(67.5)\end{array}$ & $\begin{array}{c}21.49 \pm 4.05 \\
\quad(67.2)\end{array}$ & 0.02 & $\begin{array}{c}22.06 \pm 4.12 \\
\quad(68.9)\end{array}$ & $\begin{array}{c}21.15 \pm 4.02 \\
\quad(66.1)\end{array}$ & 0.45 & $\begin{array}{c}21.62 \pm 4.1 \\
(67.6)\end{array}$ & $\begin{array}{c}22.72 \pm 4.17 \\
\quad(71)\end{array}$ & $\begin{array}{c}20.14 \pm 2.71 \\
\quad(62.9)\end{array}$ & 0.23 \\
\hline $\begin{array}{l}\text { Students' } \\
\text { perceptions } \\
\text { of } \\
\text { atmosphere } \\
(48)\end{array}$ & $\begin{array}{c}31.45 \pm 7.17 \\
\quad(65.5)\end{array}$ & $\begin{array}{c}29.53 \pm 6.52 \\
\quad(61.5)\end{array}$ & $\begin{array}{c}31.24 \pm 6.25 \\
(65.1)\end{array}$ & $\begin{array}{c}29.89 \pm 5.66 \\
(62.3)\end{array}$ & $\begin{array}{l}32.91 \pm 4.14 \\
(68.6) \\
0.007\end{array}$ & $\begin{array}{c}30.85 \pm 6.26 \\
\quad(64.3)\end{array}$ & 0.047 & $\begin{array}{c}31.77 \pm 6.39 \\
(66.2)\end{array}$ & $\begin{array}{c}30.32 \pm 6.2 \\
(63.2)\end{array}$ & 0.33 & $\begin{array}{c}31.09 \pm 6.19 \\
(64.8)\end{array}$ & $\begin{array}{c}34.16 \pm 6.07 \\
\quad(71.2)\end{array}$ & $\begin{array}{c}29.07 \pm 4.55 \\
(60.6)\end{array}$ & 0.06 \\
\hline $\begin{array}{l}\text { Students' } \\
\text { social self- } \\
\text { perceptions } \\
(28)\end{array}$ & $\begin{array}{c}18.21 \pm 4.66 \\
(65)\end{array}$ & $\begin{array}{c}16.47 \pm 4.34 \\
\quad(58.8)\end{array}$ & $\begin{array}{c}18.27 \pm 3.65 \\
(65.3)\end{array}$ & $\begin{array}{c}17.09 \pm 3.67 \\
(61)\end{array}$ & $\begin{array}{c}18.64 \pm 3.65 \\
(66.6)\end{array}$ & $\begin{array}{c}17.66 \pm 4.12 \\
(63.1)\end{array}$ & 0.10 & $\begin{array}{c}18.68 \pm 3.89 \\
(66.7)\end{array}$ & $\begin{array}{c}17.06 \pm 4.17 \\
(60.9)\end{array}$ & 0.04 & $\begin{array}{c}18.33 \pm 3.67 \\
(65.5)\end{array}$ & $\begin{array}{c}17.96 \pm 4.96 \\
(64.1)\end{array}$ & $\begin{array}{c}16.79 \pm 4.58 \\
(60)\end{array}$ & 0.54 \\
\hline
\end{tabular}

DREEM = Dundee Ready Education Environment Measure; SD = standard deviation. * Two students did not indicate gender. ${ }^{\dagger} 58$ students did not indicate their ethnicity.

The highest score was from statement 15: "The students have good friends in this school” in the first to fourth years and in the entire sample. However, statement 2: "The teachers are knowledgeable" garnered the highest scores in the final year. Students in the first year, final year and throughout all five years perceived that teaching emphasised factual learning too much as statement 25 obtained the lowest score. In the second, third and fourth years, the lowest scores were given to statements 3, 14 and 17: "There is a good support system (help) for students who get stressed", "The students are rarely bored in this course" and "Cheating is a problem in this school", respectively [Tables 3 and 4].

Statistically significant differences across all years were observed for eight statements, of which many had significantly higher scores in the first year compared to the second year. The highest mean scores for all but five statements were observed either in the first or final years of study. Statements 10, 27, 46 and 47 had their highest scores observed in the third year and the highest scores for statement 49 were reported in the second year [Tables 3 and 4].

The statements with mean scores above three, representing areas of excellence in all years, were statements 2, 15, 31 and 33: "The teachers are knowledgeable", "The students have good friends in this school", "The students have learned a lot about empathy in their profession" and "The students feel comfortable in class socially", respectively. The areas of shortcoming, as highlighted by scores $\leq 2$ over the five years, were statements 3, 14, 17, 25 and 27: "There is a good support system (help) for students who get stressed", "The students are rarely bored in this course", "Cheating is a problem in this school", "The teaching gives too much importance to factual learning" and "The students are able to memorise all they need", respectively. The other 41 statements' scores reflected areas that could be enhanced [Tables 3 and 4].

No significant gender differences were observed in the overall scores throughout the five years. Although males reported more positive scores for "social selfperceptions" $(P=0.04)$ in comparison to females across the five years of study, no other significant gender differences in subscale scores were observed [Table 2]. Males also gave significantly higher scores to ten statements than females. However, female students did not perceive that "The teachers are authoritarian" (statement 9) compared to males, therefore this was scored higher than the males $(2.29 \pm 0.91$ versus $1.95 \pm 1.01)$ [Table 5].

Significant ethnic differences $(P<0.05)$ were detected in overall scores, with students of African ethnicity (141.44 \pm 22.56$)$ generally giving higher scores than Asian (131.63 \pm 20.11$)$ or Arab students (119.43 \pm 18.02). Similarly, the subscales "perceptions of learning" and "perceptions of teachers" and 13 other statements also revealed statistically significantly differences based on ethnicity [Tables 2 and 5].

In general, students in the first and final years showed more positive perceptions as they had two $(4 \%)$ and one (2\%) statement with a mean score of $\leq 2$, and $11(22 \%)$ and $12(24 \%)$ statements with a mean score of $\geq 3$, respectively [Figure 1 ]. 
Table 3: Mean Dundee Ready Education Environment Measure statement scores of the pioneer cohort after a curricular change by year of study $(\mathrm{N}=178)$

Item

\#

\section{Students' perceptions of learning}

16 The teaching is sufficiently concerned to develop the student's competence.

20 The teaching is well focused.

22 The teaching is sufficiently concerned to develop the students' confidence.

24. The teaching time is put to good use.

Students' perceptions of teachers

2 The teachers are knowledgeable.

6 The teachers are patient with the hospital patients.

18 The teachers have good communication skills with hospital patients.

29 The teachers are good at providing feedback to students.

Students' academic self-perceptions

5 Learning strategies which worked for the students before continue to work for them now.

The students are confident about passing this year

The students' work last year has been a good preparation for this year's work.

27 The students are able to memorise all they need.

Students' perceptions of atmosphere

11 The atmosphere is relaxed during the hospital-ward teaching.

12 The timetable of this school is appropriate.

17 "Cheating is a problem in this school.

36 The students are able to concentrate well.

43 The atmosphere motivates the students as learners.

Students' social self-perceptions

$4 . \quad$ "The students are too tired to enjoy this course.

14. The students are rarely bored in this course.

15 The students have good friends in this school.
Year two Year three Yearfour Year five

$(\mathrm{n}=44) \quad(\mathrm{n}=40) \quad(\mathrm{n}=37) \quad(\mathrm{n}=35) \quad(\mathrm{n}=22)$

All responses $(\mathrm{n}=178)$

$2.95 \pm 0.65 \quad 2.43 \pm 1.11 \quad 2.68 \pm 0.85 \quad 2.54 \pm 1.01 \quad 2.91 \pm 0.68 \quad 2.69 \pm 0.9$ $P$
$=0.02$

$2.91 \pm 0.56 \quad 2.38 \pm 0.95 \quad 2.81 \pm 0.70 \quad 2.54 \pm 0.85 \quad 2.82 \pm 0.73 \quad 2.69 \pm 0.79$ $P=0.005 \quad P=0.03$

$3.0 \pm 0.48 \quad 2.63 \pm 0.87 \quad 2.73 \pm 0.77 \quad 2.66 \pm 0.84 \quad 2.82 \pm 0.59 \quad 2.77 \pm 0.74$ $P=0.04$

$2.91 \pm 0.71 \quad 2.38 \pm 1.13 \quad 2.62 \pm 0.86 \quad 2.26 \pm 1.09 \quad 2.5 \pm 0.96 \quad 2.55 \pm 0.97$ $P=0.02$

value

0.13

0.02

0.25

0.03

$3.16 \pm 0.68 \quad 3.1 \pm 0.63 \quad 3.08 \pm 0.49 \quad 3.0 \pm 0.59 \quad 3.5 \pm 0.51 \quad 3.14 \pm 0.61$

$\vec{P}=0.003$

$3.0 \pm 0.75 \quad 2.5+0.78 \quad 2.89+0.84 \quad 2.71+0.75 \quad 3.0 \pm 0.69 \quad 2.81 \pm 0.79$ $P=0.002 \quad P=0.01$

$2.91 \pm 0.88 \quad 2.5 \pm 0.91 \quad 2.76 \pm 0.93 \quad 2.51 \pm 0.98 \quad 2.95 \pm 0.79 \quad 2.71 \pm 0.92 \quad 0.046$ $P=0.02$

$2.2 \pm 0.98 \quad 1.83 \pm 1.24 \quad 2.19 \pm 1.02 \quad 2.34 \pm 1.06 \quad 2.73 \pm 0.99 \quad 2.21 \pm 1.09 \quad 0.04$

$2.52 \pm 0.9 \quad 1.93 \pm 1.14 \quad 2.24 \pm 0.98 \quad 2.43 \pm 0.92 \quad 2.5 \pm 0.96 \quad 2.31 \pm 1 \quad 0.053$ $\vec{P}=0.007$

$3.02 \pm 0.79 \quad 2.6 \pm 0.93 \quad 3.38 \pm 0.72 \quad 2.89 \pm 0.8 \quad 2.82 \pm 0.91 \quad 2.95 \pm 0.86 \quad 0.002$ $P=0.04 \quad>\quad>0.001 \quad P=0.006$

$3.07 \pm 0.7 \quad 2.68 \pm 0.83 \quad 3.05 \pm 0.74 \quad 2.89 \pm 0.76 \quad 2.45 \pm 1.01 \quad 2.87 \pm 0.81$ $P=0.02 \quad>P=0.02$

$2.09 \pm 1.05 \quad 1.70 \pm 1.09 \quad 2.22 \pm 1.13 \quad 1.89 \pm 0.96 \quad 2.1 \pm 0.96 \quad 2.0 \pm 1.06$ $P=0.04$

$2.77 \pm 0.91 \quad 2.6 \pm 0.87 \quad 2.92 \pm 0.76 \quad 2.57 \pm 0.92 \quad 3.05 \pm 0.65 \quad 2.76 \pm 0.85 \quad 0.10$ $P=0.04$

$2.48 \pm \underbrace{1.05} \quad 1.83 \pm 1.15 \quad 2.24 \pm 1.14 \quad 1.86 \pm 1.26 \quad 2.05 \pm 1.29 \quad 2.11 \pm 1.18 \quad 0.07$ $\vec{P}=0.008$

$1.98 \pm 1.30 \quad 2.1 \pm 1.26 \quad 2.05 \pm 1.25 \quad 1.63 \pm 1.14 \quad 2.32 \pm 1.09 \quad 1.99 \pm 1.23$ $P=0.02$

$2.66 \pm 1.08 \quad 2.25 \pm 1.06 \quad 2.57 \pm 0.84 \quad 2.51 \pm 0.92 \quad 2.64 \pm 0.66 \quad 2.52 \pm 0.95$ $P=0.03$

$2.68 \pm 0.91 \quad 2.2 \pm 1.14 \quad 2.62 \pm 0.98 \quad 2.46 \pm 1.01 \quad 2.73 \pm 0.63 \quad 2.52 \pm 0.98$ $P=0.04$

$2.14 \pm 1.21 \quad 1.93 \pm 1.16 \quad 2.43 \pm 1.17 \quad 2.09 \pm 1.07 \quad 2.36 \pm 0.9 \quad 2.17 \pm 1.13 \quad 0.29$

$2.09 \pm 1.31 \quad 1.43 \pm 1.22 \quad 1.95 \pm 1.15 \quad 1.66 \pm 1.03 \quad 2.14 \pm 0.94 \quad 1.83 \pm 1.18 \quad 0.07$ $P=0.02$

$3.36 \pm 0.81 \quad 3.25 \pm 0.93 \quad 3.49 \pm 0.51 \quad 3.14 \pm 0.73 \quad 3.41 \pm 0.59 \quad 3.33 \pm 0.75$ $P=0.04$
01

53

02

DREEM = Dundee Ready Education Environment Measure; SD = standard deviation.

"Indicates negative statements with reversed scores. Higher scores for these statements shows that more students disagreed with the statement.

\section{Discussion}

The role of curriculum is important to the EE because curriculum changes are essentially changes in the EE. ${ }^{1}$ GMU's curricular reform emphasises a student-centred approach that had an encouraging influence on the studied EE as reflected in the significantly higher scores of second year students in the integrated curriculum. ${ }^{12}$ The results of the current study indicated that this effect was sustainable, with a positive EE maintained over five years as the curriculum progressed. 
Table 4: Mean Dundee Ready Education Environment Measure subscale statement scores without statistical significance of the pioneer cohort after a curricular change by year of study $(\mathrm{N}=178)$

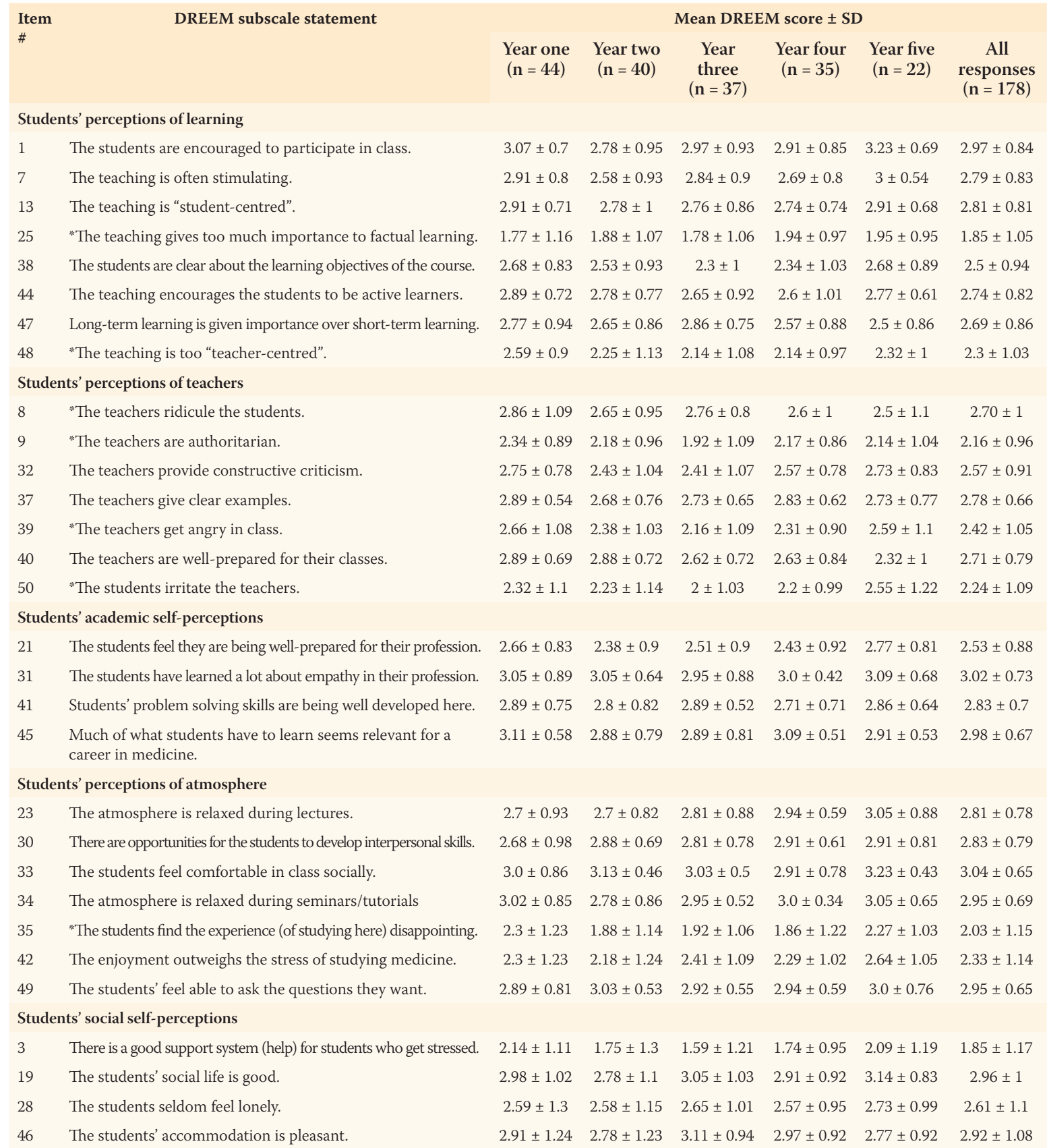

DREEM = Dundee Ready Education Environment Measure; $S D=$ standard deviation .

"Indicates negative statements with reversed scores. Higher scores for these statements shows that more students disagreed with the statement.

The EE is likely to be dynamic during the early years of a curricular change. During this phase, the educational climate needs to be closely monitored to ensure that the new curriculum is being correctly implemented and progressing in the correct direction. Additionally, any new medical curriculum should continue to be receptive to evolving trends in the community, healthcare advances and innovative teaching-learning practices; as a result, ongoing curriculum renewal becomes an essential requirement. ${ }^{18}$ The current findings, in fact, contribute to the evidencebased renewal process of the current curriculum.
The mean overall score over all five years (130/200) was higher than that reported by most medical schools in the Gulf Cooperation Council (GCC) countries, with studies from Saudi Arabia reporting scores of 107/200, 102/200, 100/200, 97/200 and 90/200; a Yemeni study reported a score of 100/200 and a study from Kuwait reported scores of $109 / 200$ and 106/200,3,7,9,19-22 Although schools in Saudi Arabia and Kuwait have similar student-centred curricula, the current EE was observed to be more conducive to learning as reflected by the higher overall score.,20,22 The well-accepted, student-centred nature of the studied curriculum, 
Table 5: Mean Dundee Ready Education Environment Measure significant subscale statement scores with gender and ethnic differences of the pioneer cohort after a curricular change across all years of study $(\mathrm{N}=178)$

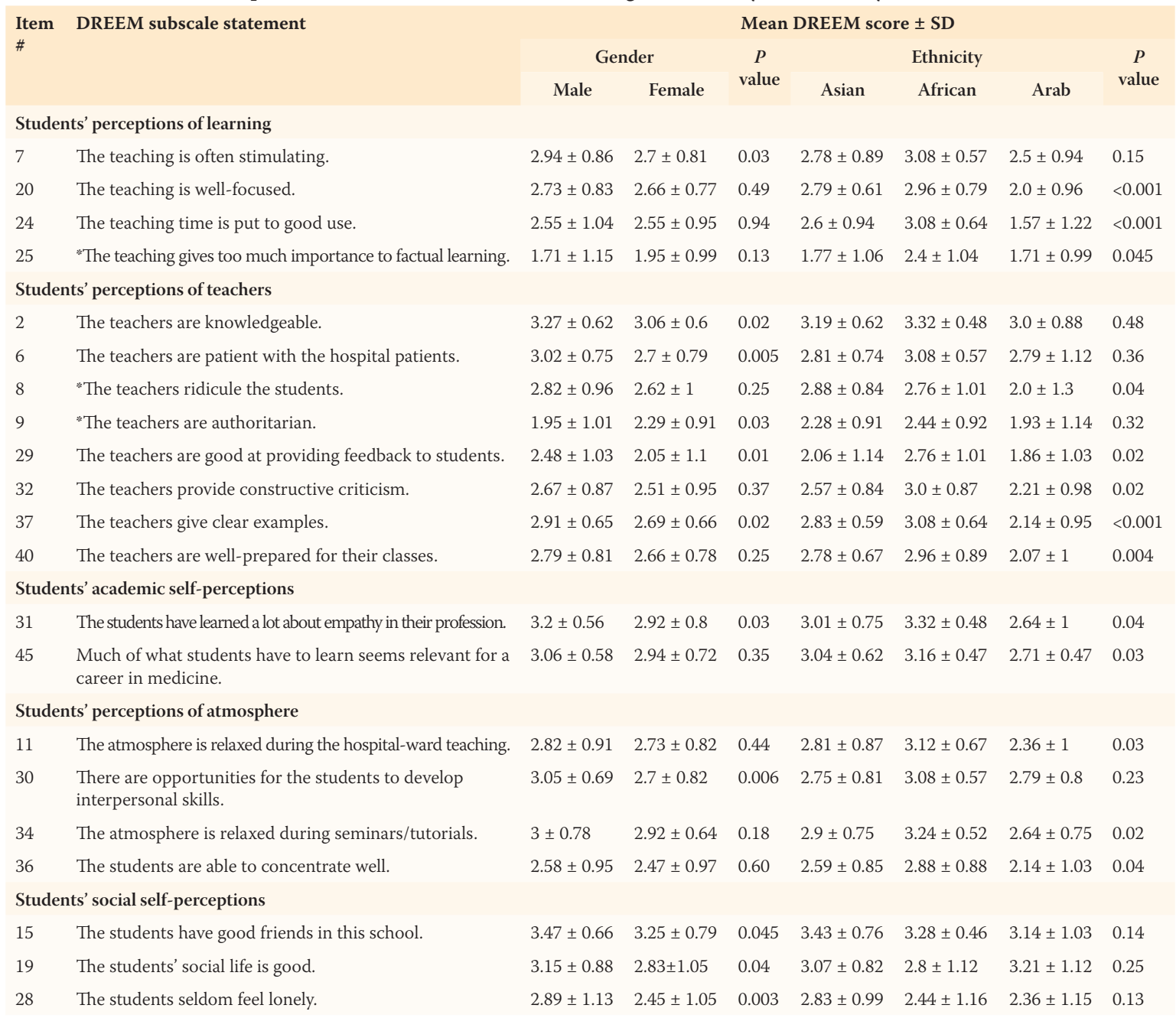

DREEM = Dundee Ready Education Environment Measure; $S D$ = standard deviation .

"Indicates negative statements with reversed scores. Higher scores for these statements shows that more students disagreed with the statement.

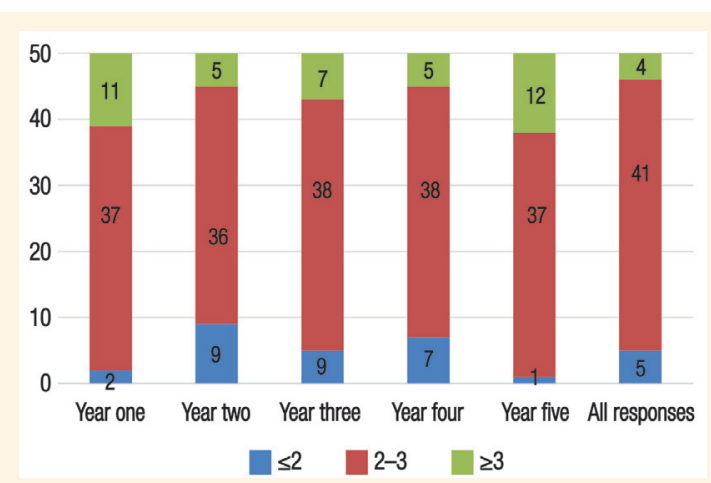

Figure 1: Mean individual Dundee Ready Education Environment Measure item scores by year of study of the pioneer cohort after a curricular change. Scores of $\leq 2$ indicate areas of shortcoming, scores of $2-3$ indicate areas that could be enhanced and scores of $\geq 3$ indicate areas of strength.

opens channels of communication with students with regular emphasis on the theoretical underpinnings of the change, the well-planned execution of the change, the backing of all stakeholders, feelings of faculty ownership, numerous faculty development programmes and continuous evaluations and feedback from students probably contributed to the positive, persistent curricular change. ${ }^{23,24}$

According to one interpretation of DREEM scores, the EE of GMU over five years was "more positive than negative" (overall score range: 101-150). ${ }^{25}$ Throughout the five years, learning was perceived to be "more positive" (subscale score range: 25-36); teachers were "moving in the right direction" (subscale score range: 23-33); academic self-perception was "more on the positive side" (subscale score range: $17-24$ ); the atmosphere was "more positive" (subscale score range: 25-36); and social self-perceptions were "not too bad" (score range: 15-21). These results emphasise the importance of consistency in maintaining a positive EE in GMU over the entire course of study of the revised programme's pioneer cohort.

The highest subscale scores for "academic selfperceptions" and "perceptions of atmosphere" indicated 
the high acceptance of the innovative curriculum with its student-centred approach whereas the lowest subscale scores in "social self-perceptions" in almost all years indicated persistent areas of shortcoming.

The adeptness of the teachers, sensitisation of students towards empathy, a camaraderie with friends and social comfort levels in the classes were identified as persistent areas of excellence with scores $\geq 3$ while an emphasis on factual learning, waning interest levels of students, a propensity towards academic dishonesty, the inability of students to memorise and a deficit of support systems for stressed students were areas of shortcoming (scores $\leq 2$ ). Most of these shortcomings have been recognised by other medical schools as well and indicate common issues faced by medical students globally. ${ }^{3-5,8,15,20,22}$ These results should aid curricular reform committees in re-examining the areas necessitating remedial interventions and allow them to consolidate areas of excellence.

Frequent faculty development programmes and familiarising teachers with the theoretical underpinnings of the new curriculum may have resulted in positive perceptions of the faculty. Continuing these programmes for new faculty members will prevent any future impediment to curricular progress. ${ }^{23}$ However, the emphasis on factual learning, students' diminishing interest levels and students' difficulty in memorising facts indicate a curricular overload and intensive efforts should be advocated to address these issues. Many studies have reported high levels of stress among medical students in all types of curricular programmes and the lack of strategies for handling this. ${ }^{26}$ Although endeavours have been made to offer a support system for stressed students in the form of academic preceptors and easier accessibility to clinical psychologists at GMU, these efforts have not been adequate. It is recommended that stress management techniques be introduced in formal training sessions from the first year to encourage stress resilience and self-care among the students. ${ }^{27}$ The predicament of academic dishonesty can be addressed by reviewing the assessment strategies and establishing an institutional culture of integrity. ${ }^{4,28}$

The DREEM scores indicated that students in the first and final year have significantly more positive perceptions of the EE. The positive perceptions in the first year may be due to initial enchantment with the novel curriculum and not a deterioration in the EE as no significant differences in the scores were observed with the subsequent two cohorts. ${ }^{29}$ Moreover, a consistent deterioration in medical students' perceptions of their EE as they proceed through a course of study, especially in hybrid delivery and problem-based learning curricula, has been previously reported. ${ }^{30}$ Positive perceptions in the final year may be due to more conducive learning experiences in the tertiary hospital supervising clinical training. Other studies have reported no such differences in perceptions about EE between different clinical training sites. ${ }^{10,11}$ These positive perceptions will also be communicated to the academic leadership with the aim of consolidating favourable learning experiences in the future.

Although no significant gender differences were observed for the overall scores, the subscale score of "social self-perceptions" and individual statement analysis indicated that males had generally more positive perceptions of the GMU programme than females. Other studies have also reported the more critical attitude of females among students from GCC countries. ${ }^{7,9}$ However, to the best of the author's knowledge, differences in perception of EE based on ethnicity have not been reported elsewhere.

Although not exactly comparable to the current study, evolutions around perceptions of EE over time have been previously investigated. ${ }^{14-16}$ Edgren et al. investigated their EEs of a Swedish school twice in a two-year period and found that their high overall score was maintained after two years of curricular reform. ${ }^{14}$ A similar study in Saudi Arabia observed a more positive EE following quality improvements compared to three years earlier. ${ }^{15}$ Another institution in Aruba reassessed their EE after six months of curricular change and recounted significant improvements in their scores. ${ }^{16}$

The limitations of the current study are the self-reported nature of the data and the inability to generalise the results due to the involvement of just one institution. These results, nevertheless, measure the sustained impact of a curricular change on $\mathrm{EE}$ for the first time in any medical school in the GCC countries. Monitoring EE by evaluating perceptions in the future will give more valuable input on the success of the school's curricular approaches. Qualitative indepth analysis of the highlighted problem areas might also act as a delimiter in this study.

\section{Conclusion}

The long-term effects of a newly introduced integrated curriculum on the EE of a medical school have been investigated for the first time anywhere in the GCC countries. The mean overall score for all responses (130/200) showed that the curricular reform had a sustained and encouraging influence on the EE at GMU throughout the pioneer cohort's course of study. The overall and subscale scores were significantly higher in the first and final years of the study. No significant gender differences were noted in the overall scores. 
The statement analyses recognised the knowledge of the faculty, students' awareness about empathy and social interactions as persistent strengths of the school over the entire course. A curricular overload, a want of support systems for stressed students, students' waning interest levels and assessment strategies emerged as areas that warranted remedial attention.

\section{ACKNOWLEDGEMENTS}

The author wishes to thank all the medical students of GMU for participating in this study.

\section{CONFLICT OF INTEREST}

The author declares no conflicts of interest.

\section{FUNDING}

No funding was received for this study.

\section{References}

1. Genn JM. AMEE medical education guide No.23 (Part 1): Curriculum, environment, climate, quality and change in medical education - A unifying perspective. Med Teach 2001; 23: 337-44. https://doi.org/10.1080/01421590120063330.

2. Roff S, McAleer S, Ifere OS, Bhattacharya S. A global diagnostic tool for measuring educational environment: Comparing Nigeria and Nepal. Med Teach 2001; 23:378-82. https://doi.org/10.10 80/01421590120043080.

3. Al-Hazimi A, Al-Hyiani A, Roff S. Perceptions of the educational environment at the medical school in King Abdul Aziz University, Saudi Arabia. Med Teach 2004; 26:570-3. https://doi.org/10.1080/01421590410001711625.

4. Bassaw B, Roff S, McAleer S, Roopnarinesingh S, De Lisle J, Teelucksingh S, et al. Students' perspectives of the educational environment, Faculty of Medical Sciences, Trinidad. Med Teach 2003; 25:522-6. https://doi.org/10.1080/0142159031000 137409 .

5. Jiffry MT, McAleer S, Fernando S, Marasinghe RB. Using the DREEM questionnaire to gather baseline information on an evolving medical school in Sri Lanka. Med Teach 2005; 27:348-52. https://doi.org/10.1080/01421590500151005.

6. Till $\mathrm{H}$. Identifying the perceived weaknesses of a new curriculum by means of the Dundee Ready Education Environment Measure (DREEM) inventory. Med Teach 2004; 26:39-45. https://doi.org/10.1080/01421590310001642948.

7. Bouhaimed M, Thalib L, Doi SA. Perception of the educational environment by medical students undergoing a curriculum transition in Kuwait. Med Princ Pract 2009; 18:204-8. https://doi.org/10.1159/000204351.

8. Riquelme A, Oporto M, Oporto J, Méndez JI, Viviani P, Salech F, et al. Measuring students' perceptions of the educational climate of the new curriculum at the Pontificia Universidad Católica de Chile: Performance of the Spanish translation of the Dundee Ready Education Environment Measure (DREEM). Educ Health (Abingdon) 2009; 22:112

9. Al-Hazimi A, Zaini R, Al-Hyiani A, Hassan N, Gunaid A, Ponnamperuma G, et al. Educational environment in traditional and innovative medical schools: A study in four undergraduate medical schools. Educ Health (Abingdon) 2004; 17:192-203. https://doi.org/10.1080/13576280410001711003.
10. Varma R, Tiyagi E, Gupta JK. Determining the quality of educational climate across multiple undergraduate teaching sites using the DREEM inventory. BMC Med Educ 2005; 5:8. https://doi.org/10.1186/1472-6920-5-8.

11. Carmody DF, Jacques A, Denz-Penhey H, Puddey I, Newnham JP. Perceptions by medical students of their educational environment for obstetrics and gynaecology in metropolitan and rural teaching sites. Med Teach 2009; 31:e596-602. https://doi.org/10.3109/01421590903193596.

12. Shehnaz SI, Sreedharan J. Students' perceptions of educational environment in a medical school experiencing curricular transition in United Arab Emirates. Med Teach 2011; 33:e37-42. https://doi.org/10.3109/0142159X.2011.530312.

13. Miles S, Leinster SJ. Medical students' perceptions of their educational environment: Expected versus actual perceptions. Med Educ 2007; 41:265-72. https://doi.org/10.1111/j.1365-29 29.2007.02686.x

14. Edgren G, Haffling AC, Jakobsson U, McAleer S, Danielsen N. Comparing the educational environment (as measured by DREEM) at two different stages of curriculum reform. Med Teach 2010; 32:e233-8. https://doi.org/10.3109/01421591003706282.

15. Mojaddidi MA, Khoshhal KI, Habib F, Shalaby S, El-Bab ME, $\mathrm{Al}$-Zalabani $\mathrm{AH}$. Reassessment of the undergraduate educational environment in College of Medicine, Taibah University, Almadinah Almunawwarah, Saudi Arabia. Med Teach 2013; 35:S39-46. https://doi.org/10.3109/0142159X.2013.765554.

16. Shankar PR, Bharti R, Ramireddy R, Balasubramanium R, Nuguri V. Students' perception of the learning environment at Xavier University School of Medicine, Aruba: A follow-up study. J Educ Eval Health Prof 2014; 11:9. https://doi.org/10.3352/ jeehp.2014.11.9.

17. Roff S, McAleer S, Harden RM, Al-Qahtani M, Ahmed AU, Deza H, et al. Development and validation of the Dundee Ready Education Environment Measure (DREEM). Med Teach 1997; 19:295-9. https://doi.org/10.3109/01421599709034208.

18. Mcleod P, Steinert Y. Twelve tips for curriculum renewal. Med Teach 2015; 37:232-8. https://doi.org/10.3109/014215 9X.2014.932898.

19. Zawawi AH, Elzubeir M. Using DREEM to compare graduating students' perceptions of learning environments at medical schools adopting contrasting educational strategies. Med Teach 2012; 34:S25-31. https://doi.org/10.3109/0142159X.2012.656747.

20. Hasan T, Gupta P. Assessing the learning environment at Jazan Medical School of Saudi Arabia. Med Teach 2013; 35:S90-6. https://doi.org/10.3109/0142159X.2013.765546.

21. Al-Ayed IH, Sheik SA. Assessment of the educational environment at the College of Medicine of King Saud University, Riyadh. East Mediterr Health J 2008; 14:953-9.

22. Karim J, Al-Halabi B, Marwan Y, Sadeq H, Dawas A, Al-Abdulrazzaq D. The educational environment of the undergraduate medical curriculum at Kuwait University. Adv Med Educ Pract 2015; 6:297-303. https://doi.org/10.2147/ AMEP.S81729.

23. Bland CJ, Starnaman S, Wersal L, Moorehead-Rosenberg L, Zonia S, Henry R. Curricular change in medical schools: How to succeed. Acad Med 2000; 75:575-94. https://doi.org/10.1097/000 01888-200006000-00006.

24. Shehnaz SI, Sreedharan J, Gomathi KG. Faculty and students' perceptions of student experiences in a medical school undergoing curricular transition in the United Arab Emirates. Sultan Qaboos Univ Med J 2012; 12:77-85.

25. McAleer S, Roff S. A practical Guide to Using the Dundee Ready Education Environment Measure (DREEM). In: Genn JM, Ed. Curriculum, Environment, Climate, Quality and Change in Medical Education-A Unifying Perspective. Dundee: AMEE Secret ariat, Centre for Medical Education, University of Dundee, 2001. Pp. 29-31. 
26. Elzubeir MA, Elzubeir KE, Magzoub ME. Stress and coping strategies among Arab medical students: Towards a research agenda. Educ Health (Abingdon) 2010; 23:355

27. Thomas SE, Haney MK, Pelic CM, Shaw D, Wong JG. Developing a program to promote stress resilience and self-care in first-year medical students. Can Med Educ J 2011; 2:e32-6.

28. Glick SM. Cheating at medical school. BMJ 2001; 322:250-1. https://doi.org/10.1136/bmj.322.7281.250.
29. Shehnaz SI, Arifulla M. The evolving educational environment in a medical school undergoing curricular change in the United Arab Emirates. Gulf Med J 2014; 3:S170-9. From: https://www. gulfmedicaljournal.com/download/supplement1_14/sup114\%20(24).pdf Accessed: May 2019.

30. Schwartz PL, Loten EG. Effect of year in school on medical students' perceptions evaluated with the Cognitive Behavior Survey, Attitudes Toward Social Issues in Medicine Survey, and Learning Environment Questionnaire. Teach Learn Med 2004; 16:333-44. https://doi.org/10.1207/s15328015tlm1604_6. 